Landina Anna,

$\mathrm{PhD}$ (Law Sciences),

Institute of State and Law V. M. Koretsky NASU, 4, Tryokhsviatitelska str., Kyiv, 01601, Ukraine

ORCID: 0000-0002-3808-7573

Nikitenko Victor,

$\mathrm{PhD}$ (Law Sciences),

Kyiv National University of Trade and Economics, 19, Kyoto str., Kyiv, 02156, Ukraine

ORCID: 0000-0002-1785-1819

\title{
INTERNATIONAL STANDARDS FOR THE PROTECTION OF THE RIGHTS OF CRIMINALS IN THE FIELD OF ENTREPRENEURIAL ACTIVITY
}

In the study of crimes' features in entrepreneurial activity the problem of protecting the rights of crime committers is set aside. In the context of globalization in the legal sphere, the issue of particular relevance is whether there are any international standards ensuring the enforcement of rights of special criminals, in particular in the field of entrepreneurial activity. European legal standards are embodied in national criminal law in the principles laid down in the national criminal law of states. When bringing a person guilty in one of these crimes to justice such international standards in respect for principle of respect and observance of human rights and fundamental freedoms come to the fore, it turns out in practice that the punishment should be imposed in full compliance with all principles for punishment imposition in a complex. The development of recommendations for the further consolidation of international standards at the level of national criminal law and their practical application determines the prospects for further developments in this direction. This will have a positive result for both national and international practice of criminal prosecution of people for committing crimes, including in the field of entrepreneurial activity.

Key words: international standards, human rights and freedoms, crime committers, principles of punishment, crimes in the field of entrepreneurial activity.

Ландіна Анна, Нікітенко Віктор. Міжнародні стандарти захисту прав суб'єктів злочинів у сфері підприємницької діяльності.

При дослідженні особливостей злочинів у підприсмницькій діяльності поза увагою залишається проблема захисту прав осіб, щзо вчинили такі злочини, а саме суб'єктів. В умовах глобалізаиії у правовій сфері особливої актуальності 
набуває питання, чи існують якісь міжнародні стандарти, щуо гарантують дотримання прав спеціальних суб'єктів злочинів, зокрема у сфері підприємницької діяльності. Європейські правові стандарти таких прав втілені у принцุипах, щзо закріплені у нормах національних кримінальних законодавств держав. При притягненні особи, винної у вчиненні одного з зазначених злочинів, на перший план виходять такі міжнародні стандарти у дотриманні прав та свобод людини, як принципи призначення покарання. На практиці виявляється, що покарання повинно призначатися у повній відповідності до загальних засад призначення покарання у комплексі. Розробка рекомендачій щзодо подальшого закріплення міжнародних стандартів на рівні національного кримінального законодавства $i$ їх практичного застосування визначає перспективність подальших розробок у даному напрямку. Це буде мати позитивний результат як для національної, так і міжнародної практики притягнення до кримінальної відповідальності осіб за вчинення злочинів, включаючи сферу підприємнищької діяльності.

Ключові слова: міжнародні стандарти, права $і$ свободи людини, суб'єкт злочину, принципи призначення покарання, злочини у сфері підприємнищької діяльності.

Topicality. The issues of crime prevention in general and in particular areas, have always been of particular relevance. These crimes include crimes in the sphere of entrepreneurial activity.

Currently, crimes in this area are gaining more and more new features; crime commitment is often associated with the use of the latest technologies. In particular, this applies to business crimes committed in cyberspace: in particular, the issues of enterprise cyber security are studied, namely, the principal components of cyber security in the enterprise economic security diagnostic system are investigated (Skrynkovskyy R., Pawlowski G., Harasym P., Koropetskyi O., 2017). Moreover, the most effective is the development of a unified international strategy to ensure cyber security, including in the business sector at the international level ( Saran S., 2016).

At the same time, the number of those crimes related to corruption and fraud in the field of entrepreneurship of various specializations does not decrease. So, there is an actual problem of fraud in the medical field of entrepreneurial activity which, according to the general calculation, makes up from 3 to $10 \%$ of expenses in this area (Clemente S., McGrady R., Repass R., Paul D., Coustasse A., 2017). One of the types of entrepreneurial activity, in which widespread fraud is also common, is the food sector, which makes analytical studies of the factors shaping the organization of food fraud important ( Lord N., Elizondo C.J.F., Spencer J., 2017).

Regarding corruption in business, the relevance of this topic is confirmed by studies of this phenomenon of doing business in a single society, in particular the People's Republic of China (Schipani S. A., Liu Junhai, Xu Haiyan, 2016; Wedeman A., 2017), Great Britain (O’Connell D., 2015). 
This issue is especially topical at the level of conducting international entrepreneurial activity from the point of view of analyzing this phenomenon and providing suggestions for overcoming it (Cuervo-Cazurra A., 2016). The problem of overcoming corruption in the field of entrepreneurial activity is especially urgent, since, as it is noted, corruption is the main problem that can restrict investments in world business, especially in emerging markets; however, enterprises operating abroad have inadequate tools to assess the risk of bribery and the possible risk of violation of various anti-corruption laws ( Stanley K. D., Loredo E. N., Burger N., Miles J. N. V., Saloga C. W., 2010).

Prevention to these crimes and combating them is an urgent necessity, since the commission of crimes in the field of entrepreneurial activity is a significant blow to the national economy of individual countries (Korobeev A. I., Kuznetcov A. V., 2017.). This will further negatively affect the global economy, since negative economic impact of these crimes often goes beyond the borders of one state and causes harm to other states, which is highlighted in modern studies (Truncevsky U. V., Osipov I. V., 2018), including the historical context of the sphere of finance and economics (Bazyuk T., 2016).

While studying the peculiarities of crimes in entrepreneurial activity, some problems are ignored, which has already been regarded. But, unfortunately, when developing certain strategies, directions, and programs to counteract these negative manifestations, in the vast majority of cases, the problem of protecting the rights of persons who committed a crime - the crime committers remains unaddressed. This also applies to special entities committing criminal offenses in the field of economic and business activities.

It should be noted that individual rules do not focus on the fact that crimes in the field of entrepreneurial activity are committed mainly by special entities.

But from the content of most criminal law norms making an offence for crimes in the field of entrepreneurial activity, it is clear that crime committer is special, that is, he is endowed with certain qualities, features and skills, without which he could not commit this crime.

But there are certain international standards guarantying the rights enforcement of the crime committers. International standard is a kind of agreement between the participating countries containing specific standard minimum transactions as for specific subject of regulation. In regards to international standards in the field of law, they are defined as a separate legal category, creating certain rights and obligations (Kiyivetc O. V., 2011).

Speaking about international standards in law, the standards on human rights protection that must be also guaranteed in the entrepreneurial sphere and industry are generally understood (Baumann-Pauly D., Nolan J., van Heerden A., Samway M.). This is due to the fact that fundamental human rights and freedoms are inherent and inalienable, and, therefore, equal for each person, regardless of citizenship and 
ethnicity. In addition, in democratic state the highest social value is a person, his rights, freedoms and interests. Exactly this determines the existence of international standards, which are not even advisory, but mandatory.

Problem statement. Crimes in the field of economic and entrepreneurial activity can be committed by the general criminal, that is, a person who has reached the age of criminal responsibility is an individual and criminally sane. In most cases, these illegal acts are committed by persons who have certain skills, are engaged in certain activities, without which they could not do these crimes. In the process of criminal prosecution, it is important to ensure the observance of the rights and freedoms of the crime committers, especially taken into account the presence of certain special features of these persons.

In the context of globalization in the legal sphere, the issue of particular relevance is the question of whether there are any international standards that guarantee the observance of the rights of the crime committers, in particular in the field of entrepreneurial activity. In addition, it is necessary to define how these international principles are embodied into national criminal law and with the help of which institutions they are implemented.

Analysis of recent researches. As for researches in this area, they are usually devoted to the prevention of white-collar crimes (such an unofficial name have the vast majority of crimes in the field of entrepreneurship). This is highlighted in the works devoted to the study of motives and personal correlates of the committers of specified crimes (Blickle G., Schlegel A., Fassbender P., Klein U., 2006); it can be traced in the development of proposals for the fight against crimes in this area (Akepe E., 2015), as well as the coverage of the main determinants, their main signs and circumstances of the commission, etc. (Iwasokun G. B., Akinyede R. O., Bello O. A., 2018). The motives of crimes in the sphere of economic activity are defined separately, in particular, on the example of specific countries (Sood G., Bala M., 2019).

Some scientists study issues related to the features of the committers of these crimes, but only in the context of committing individual crimes or on problematic issues related to criminal prosecution of these crimes, especially the investigation of these illegal acts, exemption from criminal liability for economic crimes in different countries (Korobeev A. I., Kuznetcov A. V., 2017) and so on. So, attention is paid to criminal liability for crimes in the field of small and medium-sized businesses (Zharylkapova G., Abdukarimova Zh., Kalkanova Zh., Karayeva A. 2017); a criminal law characterization of bankruptcy crimes is carried out (Bazyuk T., 2015); generalized crime studies in the field of economics as a destructive phenomenon are being carried out (Kalman O., 2012).

The most common crimes in the field of entrepreneurial activity, which are committed predominantly by special entities, are those that are committed in the banking and financial sectors, in the field of economic activity, in the fuel industry. This is confirmed by a sufficiently large number of studies on various aspects of these 
types of crimes, it is embodied in the works of scientists from different countries. So, for example, a fairly large number of developments in recent years have been devoted to the study of problems associated with crimes in the fields of finance and economics, including problems related to specific countries (Nekrasov V.A., Melnik V.I., 2017; Ocansey Evans,. 2017; Compin F., 2016; Amaefule L. I., Umeaka E.C., 2016). It proves that these crimes are among the most common in this area.

In addition, a separate aspect of crimes in the field of entrepreneurial activity is their close connection with corruption. Therefore, the issue of bringing to justice for corruption in the field of entrepreneurial activity is becoming increasingly important. (Umar H. S., Umar K., 2016; Duke Otu Offiong, Agbaji Dickson David, 2017).

But a study of namely special crime committers in the sphere of economics and entrepreneurial activity as well as the principles of guaranteeing their rights as persons who committed crimes have not been adequately covered in recent works.

The main research material presentation. Criminal prosecution should be based not only on national basic concepts, but also on certain international legal standards, which are primarily aimed at ensuring human rights enforcement at all levels of interaction (both the state and people, and people among themselves). So, for example, during criminal law relations, all rights, freedoms and interests of the parties should be ensured simultaneously and equally. But in most cases there is a situation in which the rights of the crime committers almost always remain the least protected (this is primarily a matter of fair justice and the defence of the rights of crime committers does not taken into account by a defender), although the crime committers is endowed with all human and civil rights, like other, law-abiding people (Landina A. V., 2017). Moreover, this does not depend on whether the crime committer is common or special.

Along with the fact that the main objective of the criminal law is to bring to justice the person guilty of crime, in particular in this area, this should happen within a certain legal framework set by principles of the rule of law. This principle is implemented in all, without exception, national regulatory legal acts, and it is also enshrined at the international level, which is embodied in a number of international conventions, declarations, and programs etc.

The essence of the rule of law is that it is defined as the fundamental principle of a democratic state, is an expression of the ideas of the primacy of law over the state and the priority of natural human rights in society, which is manifested in the supremacy of the Constitution and legal laws in subordination of public authorities to legal bodies (Rudniev O.), it determines that no person is also above the law. One of the most important components of this principle is respect for human rights and freedoms. Therefore, even in the case of a crime, the prosecution of the guilty person should take place in compliance with the rights and freedoms of the person a criminal.

Regarding the protection of rights and fundamental freedoms of the criminal, including the special one, these European legal standards are enshrined in the form of 
principles in the Universal Declaration of Human Rights of 1948 (hereinafter - the Declaration) and the European Convention for the Protection of Human Rights and Fundamental Freedoms of 1950 (hereinafter referred to as the Convention). These standards, like any standard in general, apply to all entities included in the scope of the relevant regulatory legal acts. Since these international regulatory legal acts apply to every person, without exception, the provisions included in these acts apply equally to people who have suffered from a crime and criminals.

The above-noted standards, enshrined in these documents from the point of view of application in relation to the crime committers, are embodied in the national criminal law and in the theory of criminal law in the form of criminal law principles and principles of assigning punishment.

Although these principles are closely related, they are not identical: the principles of punishment imposition are more special with respect to the principles of criminal law, since they relate only to the institution of punishment and the practice of its application. Since the main form of implementation of the criminal liability law is the imposition of punishment by a court, then, first of all, European legal standards are implemented in the form of imposing punishment principles, which ultimately guarantee the observance of the rights, freedoms and legitimate interests of crimes committers - the criminals.

The principles of punishment imposition include the principle of the legality; the principle of sentencing decision in the court judgment; principle of expediency of punishment; the principle of validity and mandatory motivation of punishment in the judgment; the principle of justice of punishment; principle of proportionality of punishment; the principle of humanity of punishment; the principle of individualization of punishment. Compliance with these principles provides an additional guarantee of the observance of the rights of the crime committers in the process of enforcement of criminal law when assigning punishments.

The principle of legality in punishment assigning (nullum crimen sine lege), which consists in the fact that the punishment of the guilty person is imposed solely in accordance with the norms of current legislation and cannot go beyond it, clearly reflects the provisions of Art. 7 of the Convention «Punishment solely on the basis of law», part 2 of article 11 of the Declaration of similar content, as well as Art. 9 of the Declaration («no one will be subjected to frivolous arrest, detention or exile»).

The principle of determining the punishment stipulates that the punishment should be clearly defined in the court verdict, for which the court must objectively examine all the circumstances of the case, the identity of the guilty person and determine the public danger. This principle is closely related to the previous one, since punishment should be imposed in accordance with the norms of criminal legislation, which is also a manifestation of the principle of legality. This principle is also a guarantee of compliance with the provisions of Art. 7 of the Convention and Part 2 of Art. 11 of the Declaration. 
The principle of validity of punishment and the principle of motivation for any of the punishments originates from the need to apply the punishment specifically to the person guilty of a specific crime (the crime committer), moreover it must be motivated. Each punishment must be actually (actual circumstances of a particular case) and legally (legality) justified: all actual circumstances of the case must be clearly stated, and they must have legal force, that is, they must be enshrined at the statutory level or logically flow from their content. The need to motivate punishment is based on the unity of crime and punishment, externalizes its concrete expression in the verdict, and follows from the very structure of most sanctions. This principle also guarantees compliance with the above provisions of Art. 7 of the Convention and Part 2 of Art. 11 of the Declaration.

The principle of expediency of punishment is closely related to the previous ones, since only punishment that is legal, reasonable, fair, humane and intended taking into account the individualization of criminal punishment on the one hand and the purpose and objectives of criminal law can be appropriate. The last two principles guarantee compliance with the provisions enshrined in Art. 6 of the Convention and Art. 10 of the Declaration.

The principle of justness requires compliance with the rule that the choice of a harsher punishment should depend on the nature and degree of public danger of the crime committed and the person who committed it. Under this principle, it is assumed that the punishment should take into account all the circumstances of the case, the data on the criminal, and cannot resist moral standards and beliefs, cultural values, and areas of criminal law policy. This principle guarantees compliance with Art. 3 of the Convention, which prohibits torture, inhuman or degrading treatment or punishment, Art. 5 of the Declarations of similar content; Art. 13 of the Convention guaranteeing protection to the criminal, and Art. 14 of the Convention prohibiting discrimination. With regard to crimes that can only be committed by crime committer endowed with certain features, in the imposition of punishment for crimes in entrepreneurial activity, this principle seems to be one of the most effective.

The principle of humanism in punishment imposition provides that criminal punishment should be manifested in a minimum of criminal repression against guilty people, taking into account all circumstances of the case. This applies equally to all convicted, regardless of the type of punishment (UNO Standard Minimum Rules for Non-custodial Measures - Tokyo Rules).

This applies equally to all persons regardless of the type of punishment (United Nations Standard Minimum Rules for Non-custodial Measures - the Tokyo Rules). This principle guarantees the implementation of the provisions enshrined in Art. 3 of the Convention and Art. 5 of the Declaration; part 2 Art. 6 of the Convention and Part 1 of Art. 11. Of the Declarations which reinforce the principle of the presumption of innocence; part 3 of the Art. 6 of the Convention, which states what rights the accused has; Art. 13 of the Convention. The principle of individualization of 
punishment imposition is based on the fact that the punishment is specified. This complies with the requirements of the law; legal responsibility is individual in nature and applies directly to the person who committed the crime. No one else can be responsible and liable instead of the guilty person.

There is also such a principle as the principle of proportionality (proportionality) punishment aimed at ensuring a reasonable balance of private and public interests in the legal regulation, when the goals of restricting rights must be substantial, and the means to achieve them are reasonable and minimally burdensome for the accused. This principle allows us to achieve a reasonable balance between the goals of government influence and the ways to achieve them; it is reflected in the material, and in the law of rights and in the private law (Alenin U.P., 2014). This principle guarantees compliance with Art. 18 of the Convention, Articles 2, 5-11 of the Convention and Articles 9-11 of the Declaration.

As for the indicated principles of punishment imposition specifically in the case of criminal prosecution of special crime committers in the field of entrepreneurial activity, it is in these cases that the enforcement of all rights of crime committers is very important. This is due to the fact that without a thorough study and consideration of all circumstances of the case, in accordance with the principles of punishment imposition it is practically impossible to realize criminal liability. Indeed, if it turns out that in certain cases a person does not have necessary know-how possess and skills, is not a specialist in the field of entrepreneurship (economic, banking, financial sphere), it means that he or she simply cannot commit this crime. This makes it necessary not only to assign a punishment in full compliance with the whole range of assigning punishment principles, but also to enshrine these principles in law at the level of national and international legislation.

Conclusion. So, European legal standards are embodied in the national criminal law in the principles enshrined in the criminal law of countries, including Ukraine, and ensure the enforcement of rights of crime committers while they are imposed punishment for committed crimes. This is most clearly seen in imposing punishment for such crimes in entrepreneurial activity which require the criminal to have special knowledge and skills, without which he cannot commit a specific crime in the economic, banking, and financial spheres.

When holding liable a person guilty in one of these crimes, such international standards in respect for human rights and freedoms as the principles of punishment imposition play center stage. It turns out in practice that the punishment should be imposed in full compliance with all principles of assigning punishment in a complex.

Of course, here we are talking about such an embodiment of international standards when applying the principles of imposing punishment to special crime committers in the field of entrepreneurial activity, which is the most ideal. The hard reality is that far from always the executor of law and the court take into account theoretical provisions of the criminal law. The result is that human rights are violated. 
The development of recommendations for the further consolidation of international standards at the level of national criminal law and their practical application determines the prospects for further developments in this direction. Without doubt this will have a positive result for both national and international practice of bringing guilty person a prosecution, including in the field of entrepreneurial activity.

\section{REFERENCES}

1. Skrynkovskyy R., Pawlowski G., Harasym P. et al. Cybernetic Security and Business Intelligence in the System of Diagnostics of Economic Security of the Enterprise. Path of Science: International Electronic Scientific Journal. 2017. Vol 3; No 10. https://www.pathofscience.org/index.php/ps/article/view/400

2. Saran S. Striving for an International Consensus on Cyber Security: Lessons from the 20th Century. Global police. 2016. Vol. 7. Is. 1. February: P. 93-95. doi: $10.1111 / 1758-5899.12317$

3. Clemente S., McGrady R., Repass R. et al. Medicare and the affordable care act: Fraud control efforts and results. International Journal of Healthcare Management. 2017: P. 356-362. doi: 10.1080/20479700.2017.1401277

4. Lord N., Elizondo CJF., Spencer J. The dynamics of food fraud: The interactions between criminal opportunity and market (dys)functionality in legitimate business. Criminology \& Criminal Justice. 2017. Vol 17. Is. 5. doi: $10.1177 / 1748895816684539$

5. Schipani SA., Liu J., Xu H. Doing Business in a Connected Society: The GSK Bribery Scandal in China. U. Ill. L. Rev. 2016; 63. https://heinonline.org/ $\mathrm{HOL} /$ LandingPage?handle $=$ hein.journals/unilllr2016\&div $=6 \& \mathrm{id}=\&$ page $=$

6. Wedeman A. Bribery with Chinese Characteristics? Corruption, Fuzzy Property Rights, and Rapid Growth. East Asia. 2017. Vol. 34. Is. 2: P. 87-111. doi: 10.1007/s12140-017-9272-3

7. O'Connell D. The UK Bribery Act: Challenges and opportunities for Australian business. Governance Directions. 2017. Vol 67. Is. 5. https://search.informit. com.au/documentSummary; $\mathrm{dn}=257511793204055$;res=IELBUS

8. Cuervo-Cazurra A. Corruption in international business. Journal of World Business. 2016. Vol 51. Is. 1: P. 35-49. https://www.sciencedirect.com $/ \mathrm{science} /$ article/pii/S1090951615000681

9. Stanley KD., Loredo EN., Burger N. et al. Business Bribery Risk Assessment. RAND Corporation, 2010: 75 p. https://doi.org/10.7249/RR839-1

10. Korobeev AI., Kuznetcov AV. Comparative Analysis of Legislation of Various Countries Governing Release from Criminal Liability in Cases of Crimes in the Sphere of Economic Activity. Journal of Internet Banking and Commerce. 2017. http://www.icommercecentral.com/open-access/comparative-analysis-of-legislation- 
of-various-countries-governing-release-from-criminal-liability-in-cases-of-crimes-inthe-sphere-of-economic-activity.php?aid $=71768$

11. Truncevsky U.V., Osipov I. V. Consolidation in the Law of Quantitative Parameters Cost Criteria of Crimes in Sphere of Economic Activity: Regularities and Calculation Methods. Law: J. Higher Sch. Econ. 2018, 122. https://heinonline.org/ $\mathrm{HOL} /$ LandingPage?handle $=$ hein.journals/pravo2018\&div=39\&id $=\&$ page $=$

12. Bazyuk T. The History and Development of Economic and Financial Crimes in Ukraine and the World. Jurid. Sci. 2016, 66. https://heinonline.org/HOL/ LandingPage?handle $=$ hein.journals/juridsce2016\&div $=11 \&$ id $=\&$ page $=$

13. Kyivets O.V. European legal standards as an international legal // European Studios and Law № 1 (5) for 2012. Electronic resource. Source access: http://eurolaw. org.ua/11-ukrainian-journal-of-european-studies/1-5-2012/44-2011-12-29-14-

14. Baumann-Pauly D., Nolan J., van Heerden A. et al. Industry-Specific MultiStakeholder Initiatives That Govern Corporate Human Rights Standards: Legitimacy assessments of the Fair Labor Association and the Global Network Initiative. Journal of Business Ethics. 2017. Vol. 143. Is. 4: P. 771-787. https://link.springer.com/ article/10.1007/s10551-016-3076-z

15. Blickle G., Schlegel A., Fassbender P. et al. Some Personality Correlates of Business White-Collar Crime. Applied Psychology. 2006. Vol. 55. Is. 2. P. 220-233.

16. Enobi A. Fighting White-Collar Crimes Using Forensic Investigation Skills to Enhance Operational Efficiency - Cameroon as a Case Study. 2015. https://ssrn. com/abstract $=2579587$ or http://dx.doi.org/10.2139/ssrn.2579587

17. Iwasokun G.B., Akinyede R.O., Bello O.A. Principal Components-based Investigative Study of Counter Measures to Financial Crimes. International Journal of Financial Research. 2018. Vol. 9(2). P. 150-164. https://papers.ssrn.com/sol3/ papers.cfm?abstract_id $=2579587$

18. Sood G., Bala M. White Collar Crimes in India. International Journal of Trend in Scientific Research and Development (IJTSRD). 2019. Vol. 3. Is 4. https://www.researchgate.net/publication/334123696_White_Collar_Crimes_in_India

19. Zharylkapova G., Abdukarimova Zh., Kalkanova Zh. et al. General Legal Characteristic and Classification of Crimes Committed in the Sphere of Small and Medium Business. Journal of Advanced Research in Law and Economics. 2017; Vol. 8; Is. 5(27). doi:10.14505/jarle.v8.5(27).34

20. Bazyuk T. On the Issue of Criminal-Legal Characteristic of Crimes in the Sphere of Bankruptcy under the Legislation of Ukraine and Some Foreign Countries. Jurid. Sci. 2015; 117. https://heinonline.org/HOL/LandingPage?handle=hein.journals/ juridsce $2015 \&$ div $=248 \&$ id $=\&$ page $=$

21. Kalman O. Crimes in the Sphere of the Economy. Law Ukr.: Legal J. 2012; 38. https://heinonline.org/HOL/LandingPage?handle=hein.journals/lwukrn2012 $\&$ div $=101 \&$ id $=\&$ page $=$ 
22. Landina A.V. Securing the right of a criminal by the principles of criminal law. Judicial appeal. № 1 (46). 2017. P. 66-73.

23. Nekrasov V.A. Melnyk V.I. Application of SWOT and PESTEL Analysis in Combating Economic Crimes and When Identifying Threats to Economic Security of the State. Probs. Legality. (2017); 193. https://heinonline.org/HOL/LandingPage? handle $=$ hein.journals/proble136\&div $=23 \&$ id $=\&$ page $=$

24. Evans O. Forensic Accounting and the Combating of Economic and Financial Crimes in Ghana. European Scientific Journal. 2017. Vol. 13; No. 31. https://pdfs. semanticscholar.org/5e22/6caa8c4b5c1e6f363f36e1a5b2856b5d1c7c.pdf

25. Compin F. Do financial criminals commit perfect crimes? Journal of Financial Crime. 2016. Vol. 23. No. 3. P. 624-636. doi.org/10.1108/JFC-03-2015-0018.

26. Amaefule LI., Umeaka EC. Combating Economic And Financial Crimes By The AntiGraft Agencies In Nigeria: Implications on the Nation's Economic Growth and Development. International Journal of Innovative Development \& Policy Studies. 2016. 4(2). P. 8-33. https://seahipaj.org/journals-ci/june-2016/IJIDPS/full/IJIDPS-J-22016.pdf

27. Umar HS., Umar K. The Economic and Financial Crimes Commission and Corruption Management in Nigeria: a Perceptual Assessment of its Legal Framework. Journal of Siberian Federal University. Humanities \& Social Sciences. 2016.2 (9): P. 310-317. http://elib.sfu-kras.ru/handle/2311/20092

28. Duke O.O., Agbaji D.D. The Pursuit of Good Governance and the AntiFinancial Corruption Blitz in Nigeria: A Study of the Economic and Financial Crimes Commission. 2017. Vol 2. Is. 4: P. 1-16. doi.org/10.9734/ARJASS/2017/32115

29. Rudniev O. International standards of human rights and the principle of the rule of law: the problem on the correlation of legal phenomena. URL: http://www. pravnuk.info/urukrain/1456-mizhnarodni-standarti-prav-lyudini-ta-principverxovenstva-prava-do-problemi-spivvidnoshennya-pravovix-yavishh.html

30. Alenin $\mathrm{Yu}$. P. The concept and system of principles of criminal proceedings / Yu. P. Alenin, V. K. Voloshyna// Scientific works NUOJA. 2014. T. XIV. P. 78-89. 